\title{
天竜川河口部における砂碟の選択的移動特性と砂州の変形機構

\author{
Selective Movements of Sand and Gravels and Resulting Morphology Change around \\ the Tenryu River Mouth
}

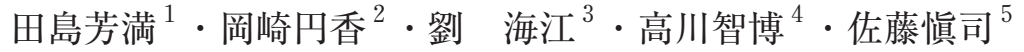 \\ Yoshimitsu TAJIMA, Madoka OKAZAKI, Haijiang LIU, Tomohiro TAKAGAWA and Shinji SATO
}

\begin{abstract}
This study investigates physical mechanisms of eastward extension of the sand spit at the Tenryu River mouth. Shoreline profiles of the sand spit, extracted from successive still images recorded by a field camera, were first compared with hydrodynamic characteristics such as waves, river flows and tides. Color sand and gravels were used as tracers to capture the characteristic movement of sediments on and around the sand spit. Tracers placed in the swash zone around the middle of the sand spit moved westward while the ones around the east end of the spit moved eastward. Clear difference between sand and gravels was also observed especially in their moving directions. Image and numerical analyses were finally carried out to investigate the hydrodynamic characteristics that caused such characteristic movements of sediments.
\end{abstract}

\section{1. はじめに}

河口部で発達する砂州地形は, 周辺の波, 流れ場や, それに基づく砂礫の移動特性を規定するが，同時に複雑 かつ活発な砂礫の移動は, 河口砂州地形を絶え間なく変 形させる.このように相互干渉しながら動的に変容する 河口砂州周辺環境の特性は, 水中設置型の計測機器によ る直接的観測が困難であり, 現地実測データに基づく実 証的な知見の蓄積が十分に進んでいるとは言い難い.

このような厳しい制約条件の下，河口域の観測には航 空写真やビデオ画像, 平常時の深浅測量データが用いら れることが多い（例えば, 佐々木ら，1987；真野ら， 1995 ; 宇多ら, 1994 ; 田島ら，2008）。これらの研究に より, 出水時にフラッシュした河口砂州は, 平常波浪時 に砂州先端部を延伸するように回復することや, その変 形特性は河口テラス形状と強い相関を持つことなどが報 告されているが, 実際の波, 流れ, 漂砂移動と河口砂州 地形変化との関係について, 詳細な検討はなされていな い. そこで本研究では, 天竜川河口砂州を対象とし, ト レーサー追跡を含む高頻度観測に基づき, 砂礫の移動特 性と砂州の変形機構の解明を試みる.

\section{2. 現地観測の概要}

現地調査は天竜川河口砂州が大きく変形した 2009年 7 月から 10 月を対象期間とした。図-1に天竜川河口域と調

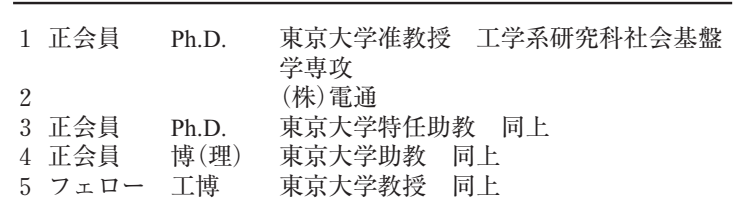

査の概要を整理する.まず砂州地形の変形特性を把握す る目的で, 砂州先端部や 2007 年台風 4 号来襲時における 決壊部（田島ら，2008）を中心に合計7回の地形計測を 実施した。さらに，図に示した3地点に定点観測カメラ を, 1 地点にX-band radarを設置し, 刻々と変化する天竜 川河口周辺地形や周辺の波・流れ場を，それぞれ 1.2 秒, 2秒間隔で, 連続観測した。

また，7月28日には図に示した砂州上の2 地点に, 着 色砂（粒径 $0.2 \sim 0.4 \mathrm{~mm}$ ) および市販の風水砂利（粒径 1 〜 $3 \mathrm{~cm}$ ）をそれぞれ $250 \mathrm{~kg}$ ずつ投入し, その後の移動状 況を以下の方法で追跡した。 まず着色砂については, 表 層約 $1 \mathrm{~cm}$ の砂を無作為に約 $100 \mathrm{~g}$ ずつ採取し, 上山ら （2009）と同様の手法を用いて, サンプル中に含まれる 着色砂の含有率を推定した。この際, 着色砂の計数には 齊藤ら（2010）が改良を加えた自動計数装置を用いた. また採取地点について, 沿岸部では投入地点を中心に汀 線に沿って, 採取時の波の最大遡上位置から海側に約 $1 \mathrm{~m}$ 入った地点を対象とした。一方, 先端部では海浜部を $10 \mathrm{~m}$ 四方の領域に分割した格子地点でサンプリングを行 った. 次にトレーサー碟については, 発見地点の位置座 標を記録するとともに, 表層部の写真撮影を行い, 単位

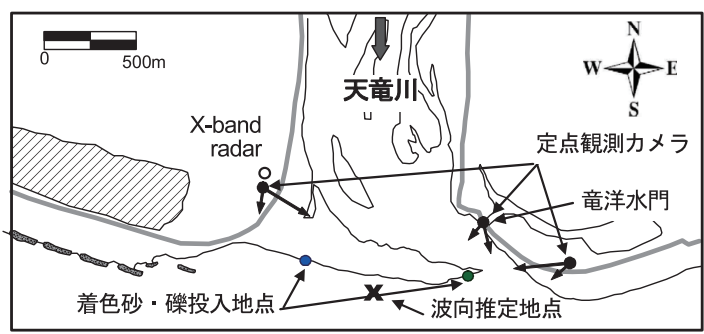

図-1 天竜川河口域と調查概要 
面積あたりのトレーサー礫の個数を数えた.

観測期間中の波・流れ場については，画像観測データ の分析に加え, 鹿島地点（河口から約 $25 \mathrm{~km}$ 上流）におけ る水位データに基づく河川流量，図-1に示した竜洋水門 における潮位観測データ，河口沖水深 $40 \mathrm{~m}$ 地点に位置す る竜洋波浪観測点での波浪デー夕をそれぞれ分析した。

\section{3. 砂州の変形}

\section{（1）变形特性の定量化}

GPSを用いて計測した河口砂州全体の水際線位置の比 較を図-2に示す。図に見られるように，砂州は，主に海 側および先端部で顕著に変形している。ただし，10月に は砂州の陸側で水際線位置が大きく北側に移動している が，これは台風 18 号の通過に伴い来襲した有義波高 $10 \mathrm{~m}$ 強の高波浪によるものである（高川ら，2010）。また 8 月 16 日から9月24日にかけては，汀線が砂州西側で沖向き に前進，東側で陸向きに後退しており，この期間には西 向き漂砂移動が卓越的であったことが推察される。

次に，特に変形が著しかった砂州先端部に着目し，定 点観測画像に基づき先端部平面地形の時間変化をより高 頻度に追跡した。平面地形の抽出に用いた画像は，竜洋 水門での潮位が $\mathrm{TP}+0.0 \mathrm{~m}$ であったときのもののみを用 い, 砂州先端部周辺での合計 8 点の基準点座標に基づき, 原画像を座標変換して砂州先端部を上空から見た平面画 像を作成した（図-3）。図には原画像（スナップ写真）と その変換画像の例を示すが，水際線の平均位置を抽出す る際には，同じ潮位条件時 $(\mathrm{TP}+0.0 \mathrm{~m})$ における 1 分間 の平均画像を用いた。このようにして得られた 107 組の 画像に対して水際線位置を抽出し，その一部を比較した ものを図-4に示す。図中の数字は撮影日を示しており (例えば 1002 は 10 月 2 日), 水際線位置が日スケールで激 しく変動しているのが分かる.

次に, 砂州の変形と外力条件との関係を分析するため, 砂州先端部を図-4に示した東西および南北の測線で，そ れぞれ2領域に分割し，各々の領域における陸域面積を算 定した。得られた陸域面積と外力場の経時変化を図-5に 比較する．図の波向は，河口砂州の変形に直接影響をお よぼす砂州前面地点（図-1）における值として，X-band radar画像（図-6）から波峰線追跡法に基づき推定した. 図-6に示した時刻における波向の推定值は $\mathrm{S} 12^{\circ} \mathrm{W}$ となっ ており，妥当な推定結果が得られていると考えられる.

\section{(2) 砂州変形特性と外力場との関係}

図-2〜図-6の比較をもとに，砂州先端部の地形変化と 外力場との関係を，時間経過とともに整理する。

まず，対象期間中に唯一有意な出水が見られた 7 月 27 日以降の数日間では，砂州先端部の主に北東部が削られ ており，波浪よりも河川流による影響が卓越的であった
ことが推察される.しかしながら，その後の有義波高 2 〜 $3 \mathrm{~m}$ 程度の高波浪時と比べても，砂州面積の変化量は 相対的に小さいことが分かる.

次に8月9日には台風9号に伴いやや西寄りからの高波 浪が来襲し，領域 $\mathrm{S}$ およびNで，それぞれ大きく減少， 増加した.これに対して領域Eにおける増加量は小さい ことから，高波浪時には沿岸漂砂よりも，砂州上の越波 に伴う北向きの漂砂移動の方が卓越的であったことが推 察される。また，その後はしばらく低波浪が続き，8月 15 日には砂州先端部の南側に形成されていた浅瀬が陸上 部に現れて領域 Sを増大させた。この浅瀬の東西位置を 境に先端部の南北への移動状況が著しく変化することか ら，浅瀬出現部よりも西側では，高波浪時にも越波が起 こらず，高波浪によって沖側に運ばれた砂がその後 1 週 間程度の低波浪によって汀線際に戻されたために，浅瀬 が形成されたと考えられる。

また 8 月中頃から 9 月にかけては，東寄りからの来襲 波が卓越し，図-2に見られた砂州西側における汀線の大 幅な前進と符合する。その一方で，領域 $\mathrm{E}$ は比較的安定 であり，週 1 回の頻度で来襲した有義波高 $2 \mathrm{~m}$ 程度の高波 浪よりも，大潮の時期と連動して面積が周期的に変化し ているように見える。これは，領域 $\mathrm{E} の$ 標高が低く，越 波による影響を強く受けたためであると推察される.

低波浪が長く続いた9月 20 日以降は，北側に押し込ま れた砂州先端部が徐々に延伸し，領域 N P Eで継続的な 増加が見られた。またこの期間はやや西寄りからの波が 卓越し，他の低波浪期間と比べても領域 $\mathrm{E} の$ 増大速度が 大きかった。

最後に 10 月 7 日の台風 18 号の来襲により，有義波高が $10 \mathrm{~m}$ を超える高波浪が来襲し，砂州のほぼ全域で越波が みられた（高川ら，2010）。台風前後の深浅測量データ から推定した北向き土砂移動量の沿岸方向分布は，砂州 の標高と強い相関を有しており，このことからも，高波 浪時における北向きの土砂移動は，越波によるものであ ることが分かる。

\section{4. 着色砂礫の追跡調査による移動特性の検証}

次に7月 28 日に投入した着色砂および碟の追跡調査の 結果を分析し，既に整理した外力場や砂州の変形特性と の関係を考察する.

砂州中央部および先端部の遡上帯に投入した着色砂お よび礫の追跡結果を，それぞれ図-7および図-8に示す。 図中の着色砂および碟の量はそれぞれサンプル中の重量 含有率 $(\mathrm{ppm})$ ，単位面積あたりの個数で表している。ま た図-8に示した様に，着色砂は一点に投入したのに対し， 砂州先端部の礫は, 図の破線に沿って均等に投入した。

図-7見られるように，砂州中央部に投入した着色砂は 


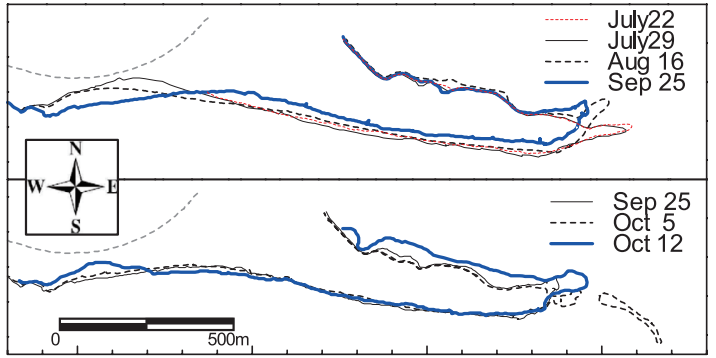

図-2 河口砂州形状の時間変化

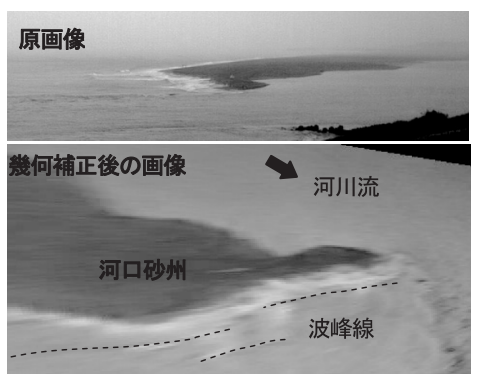

図-3 定点観測カメラによる静止画像と座標変換後の画像

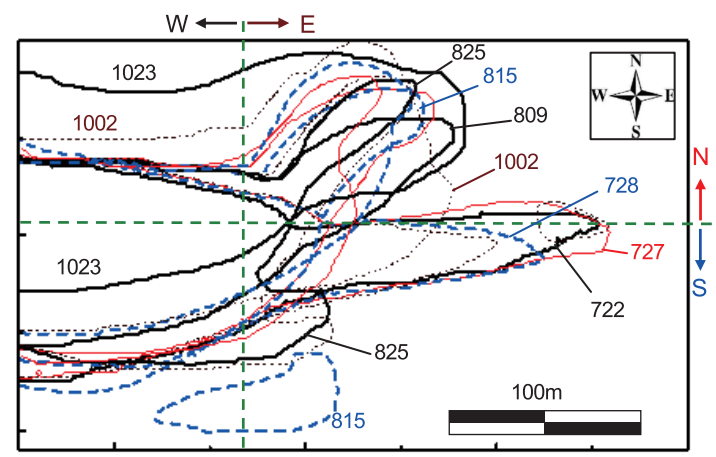

図-4 砂州先端部の変形と陸域面積の算定領域

全て西向きに移動し，その移動距離は 10 時以降に急激に 拡大している。着色砂を投入した 7 時が上げ潮で潮位 $\mathrm{TP}+0.1 \mathrm{~m}$ であったのに対し，10時から11時にかけて満潮 （TP+0.4m） となったことから，遡上帯に投入した着色砂 の移動量が潮位による影響を強く受けていることが分か る.一方，礫は砂に比べて沿岸方向への移動量が小さか ったが，その移動方向は全て西向きであった．7月28日 のX-band radarによる砂州前面での波向きは真南からや や東寄りであり，また竜洋波浪観測点における平均波向

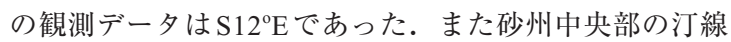
は東西方向から時計周りに約 17 度傾いており，このこと からも, 着色砂拈よび砂の西向き移動は外力場や, 図-2 で見られた西向き漂砂による砂州の汀線変化とも整合し ている.

一方，砂州先端部に扔ける着色砂㧍よび啋は，北東方

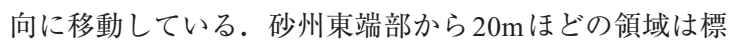

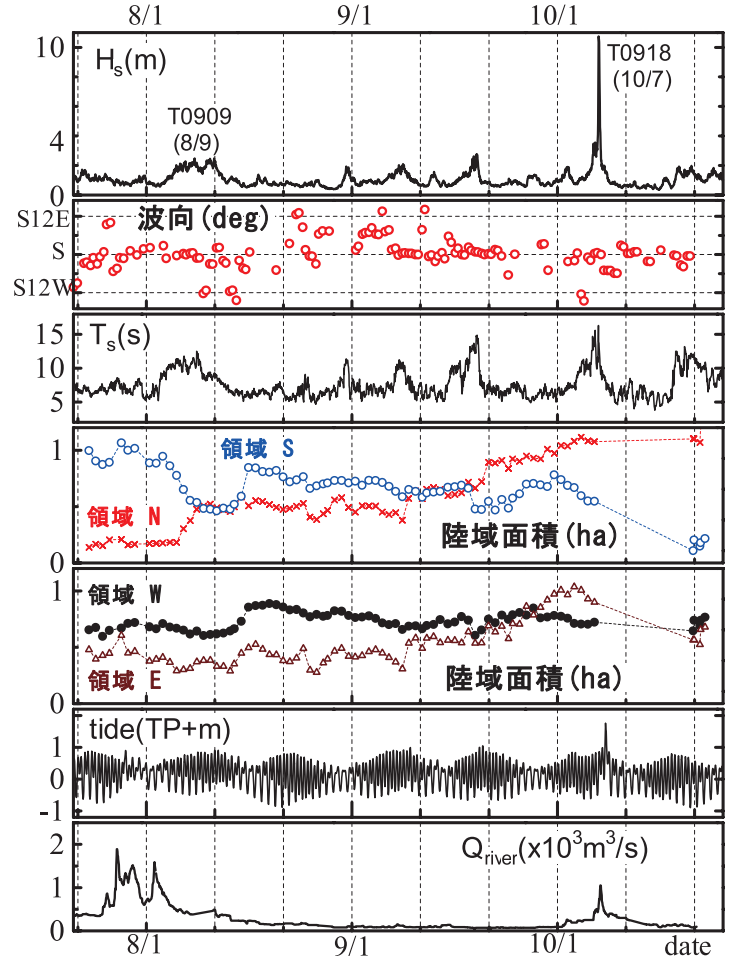

図-5 有義波高，波向（砂州前面），有義波周期，砂州先端部 領域（N,S,E,W）における陸域面積，潮位，河川流量の 経時変化

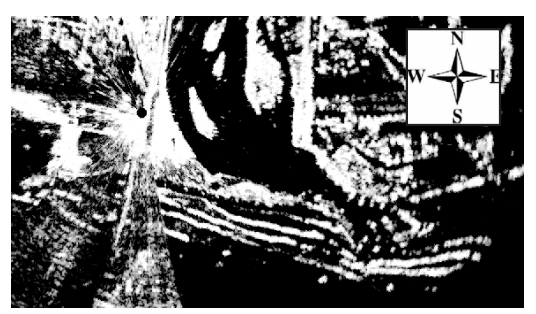

図-6 X-band radarによる観測画像例（8月8日2時）

高が低く, 越波や潮汐による冠水が頻繁にあった地点で, サンプリングができなかった領域である，砂を採取して 分析したが着色砂が含まれていなかった地点について は，図-8中に黒丸で示している.

また砂と砂の移動状況の違いに着目すると，28日22時 の満潮（TP+0.7m）を経過した後の29日13時において， 磁は着色砂に比べてより北側に運ばれている様に見える. これについては，次節の外力場の分析で考察を加える.

以上に見られたように，調査実施日はやや東よりから の来襲波が卓越していたにも関わらず，砂州中央部では 西向き, 先端部では東向きと, 砂礫の移動方向が異なっ ていたことが明らかとなった。 また砂州中央部では前浜 勾配が大きく，礫は海側へと流失する傾向が見られたの に対し, 先端部では陸側 (北側) へと移動する傾向が見 

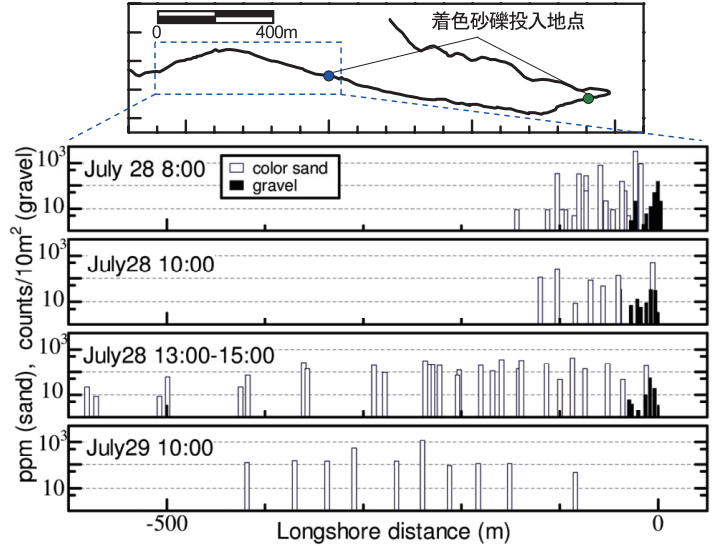

図-7 砂州中央部に抢ける着色砂・礫の追跡結果

られた．砂州先端部における砂砂の北向きの移動傾向は, 高波浪時における砂州先端部の北側での堆積が，河川側 からの土砂供給によるものではなく, 越波に伴い砂州を 越えて運ばれた海域からの土砂供給によるものであると 演繹した前節の砂州先端部の変形特性の考察と符合する.

\section{5. 河口砂州周辺における外力場の特性}

砂州周辺部における砂礫の移動特性と砂州の変形特性 を規定する波・流れ場について，画像デー夕と数值解析 に基づき分析する. 本研究で着目する水理現象としては, 河口域に打ける波と流れの干渉や䂶波, 砂州上への遡上 などが挙げられる。これらの水理現象を同時に効率良く 再現可能な数值モデルとして，透水層を考虑した修正ブ シネスク方程式に砕波減衰モデルを導入し，現地地形条 件や潜堤周辺などの複雑な計算条件下での適用性も確認 されている田島ら（2006）のモデルを用いた．計算領域 は天竜川河口域を含む南北に $1.25 \mathrm{~km}$, 東西に $2.5 \mathrm{~km}$ の範 囲とした。地形条件は国土交通省による8月の詳細深浅 測量デー夕に基づき $5 \mathrm{~m}$ 四方の正方格子デー夕を作成し て用いた。入射波条件は，着色砂追跡調查時の7月 28 日 の 10 時を想定し，竜洋波浪観測所における同時刻の波浪 条件（有義波高 $80 \mathrm{~cm}$, 周期 $7.8 \mathrm{~s}$, 波向 $\mathrm{S} 12^{\circ} \mathrm{E}$ ）を与えた. 入射波特性は, 有義值をそのまま用いた規則波と, 周波 数スペクトルをエネルギー等分割して算定した個々波 を，ランダムに設定した位相差で重ね合わせて作成した 単一方向不規則波の両者とした．また河川流については 上流側境界で流量を与えて導入したが，波・流れ干渉に よる影響を検証するため，流量を変化させた複数の計算 を実施した。

\section{（1）砂州先端部周辺の越波}

15 分間の連続画像デー夕に基づき, 次の手順で河口砂 州先端部に扔ける浸水率を算定した。まず原画像におけ る砂州先端周辺の陸 - 水域の RGB值を確認し, 試行錯誤

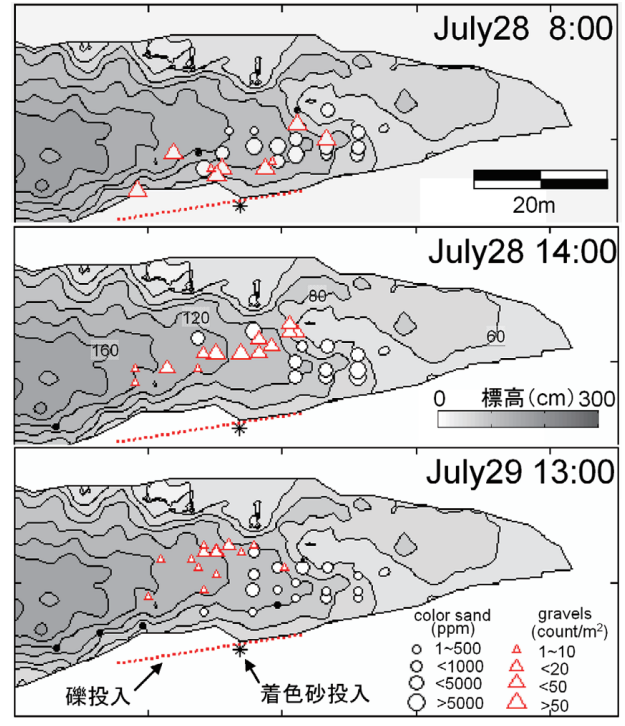

図-8 砂州先端部における着色砂・礫の追跡結果

により決定した閾值に基づき画素情報を二值化した，次 に得られた画像に座標変換を施し, 得られた連続静止画 像から任意対象地点での没水時間を数え, 最後に作成し た連続画像の全時間で除して浸水率を算定した。このよ うにして推定した28日7時および10時における浸水率の 平面分布を図-9に示す。また図には，10時の条件におい て，規則波および単一方向不規則波を入射させて計算し た浸水率も示した.

潮位の変化に伴い，先端部周辺の浸水領域は大きく変 化し, 特に緩勾配な海岸線前面および先端部で遡上域が 拡大していることが分かる．また数值計算では，入射波 の不規則性を考慮することによって，このような砂州先 端部での遡上域の広がりを定性的に再現できている。さ らに, 砂州先端部に抢ける砂砂の追跡調査では, 礫の方 がより北向きに移動する傾向が見られたが，これは着色 砂が常時移動するのに対して, 磼は時折来襲する比較的 周期の長い大きな波が砂州上を越波したときのみに移動 したと考えれば，来襲波の不規則性による影響のひとつ として，ここで示した数值解析結果とも整合する.

\section{（2）河口域周辺の波向}

規則波を入射させ，河川流量をゼロまたは竜洋水門前 面の流速計測結果 $(1.4 \mathrm{~m} / \mathrm{s})$ に整合させた $280 \mathrm{~m}^{3} / \mathrm{s}$ とした 場合，また同じ流量で単一不規則波を入射させた場合に おける波浪変形計算結果の瞬間波形を図-10に比較する. また図には，計算に用いた計測地形の等深線も合わせて 示した。図に見られるように，河川流の影響により，砂 州先端部の沖側で波が集中し, 河口砂州前面における波 峰線や波高の分布に有意な影響を及ぼしていることが分 かる。また不規則波を入射させた計算結果では，河口テ 


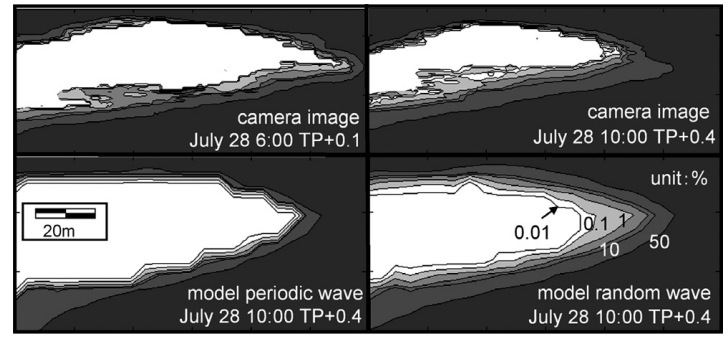

図-9 連続画像およびモデルによる浸水率（\%) の比較

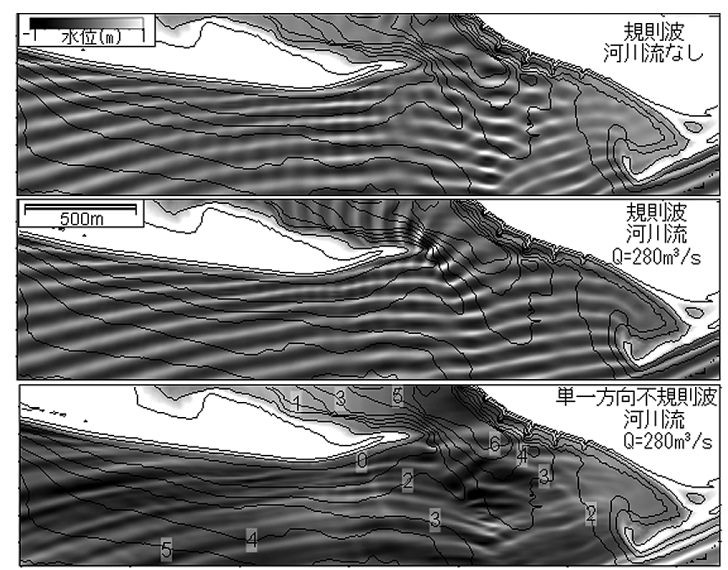

図-10 モデルによる河口域周辺での瞬間波形の比較

\section{ラス部における屈折変形がより顕著に表れている.}

次に時々刻々の流速の計算結果から, 水深 $1 \mathrm{~m}$ 地点に 扔ける平均波向を推定し，その沿岸方向分布を比較した (図-11 (a))。図の横軸は砂州東端部（開口部）からの距 離であり, P は規則波, $\mathrm{R}$ は不規則波を入射させた時, 数字 $0 \sim 2$ は, 河川流量を $Q=0,140,280 \mathrm{~m}^{3} / \mathrm{s}$ とした時の計 算結果を示す。また太破線は, 同時刻の座標変換画像 （図-3）に扔ける波峰線の分布から推定した波向である. 図-11（b）は波向と同定義の汀線法線方向，(c) は（a） と（b）の差分であり, 正の值は法線に対して波向が反 時計回り方向に傾き, 結果として西向きの漂砂移動を引 き起こす．眓に見られるように，波向は先端部 $(x=0 \mathrm{~m})$ から西に向かって, 約 $100 \mathrm{~m}$ の範囲で急激に増加し, ピ ークに達した後, 西に向かってテラス地形の影響によっ て徐々に減少している. 数值モデルでは, 画像に見られ たこのような定性的傾向を妥当に再現している．また河 口付近 $(0<x<500 \mathrm{~m})$ では河川流によって波向がより南寄 りへと変化し, 河川流が先端部の土砂の東向き移動特性 を助長していることが分かる.また不規則波を入射させ た条件では，河川流による影響範囲が拡大している.

一方で, 東西方向の汀線角度の変化は波向に比べても 大きく, 両者の差（図-11 (c)）を比較すると, 砂州先端 部における東向きの土砂移動特性には, 河川流による波

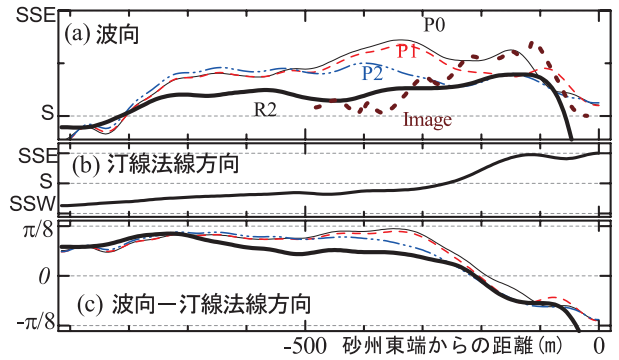

図-11 モデルおよび画像による砂州前面での波向分布

向の変化よりも越波に伴う砂州先端部の北向移動とその 後の河川流の作用による東向移動の方が, より卓越的に 寄与していることが推察される。

\section{6. おわりに}

天竜川河口砂州を対象とし, 高頻度観測と着色砂礫の 追跡調查に基づき, 河口砂州先端部の延伸過程の解明を 試みた。標高の低い砂州先端部では越波による陸向きの 漂砂移動が卓越し, 結果として生じる砂州先端形状の変 化や河川流による影響は, 来襲波向に寄らず先端部の延 伸過程を助長していることなどが明らかとなった。

本研究は, 科学技術振興調整費重要課題解決型研究 「先端技術を用いた動的土砂管理と沿岸防災」の研究成 果の一部であり, 国土交通省浜松河川国道事務所および 静岡県より貴重なデータをご提供いただいた．記して深 甚な謝意を表する。

\section{参 考 文 献}

上山 聡- 牛 小静・和田麻美 - 劉 海江 - 高川智博 - 田島 芳満・佐藤買司（2009）：波浪の侵入が卓越する河口エス チュアリーに拀ける波・流れ場と土砂移動, 土木学会論 文集 (海岸工学), B2-65, No.1, pp.456-460.

宇多高明 - 鈴木忠彦 · 大石守伸 - 山本雅彦 - 大谷靖郎 (1994)：天竜川河口砂州の伸長に伴う河岸侵食と海浜変 形, 海工論文集, 第41巻, pp.481-485.

齋藤晴久 ·坂本 繁・鈴木 誠 - 尼崎貴大 - 加藤 茂 - 青木 伸一・上山 聡・佐藤懭司 (2010)：土砂動態の高頻度モ ニタリングのための着色砂分析システムの開発, 土木学 会論文集 (海岸工学), B2, (印刷中).

佐々木隆士 ·宇多高明 - 刀襧 賢・菅原信雄 - 海野 仁 (1987)：洪水流による河口砂州のフラッシュ観測，第 34 回海工論文集, pp.327-331.

高川智博・斉藤正一郎・上山 聡・田島芳満・劉 海江・武 若 聡・佐藤愼司 (2010) : 台風0918号時の高波浪による 天竜川河口砂州周辺の土砂移動実態の解明, 土木学会論 文集 (海岸工学), (印刷中).

田島芳満・佐藤㥍司・藤原弘和 (2006)：Hurricane Katrinaに よるBiloxi周辺の高潮被害分布とその外力特性の検証，海 工論文集，第53卷，pp.406-410.

田島芳満 - 高川智博 - 浅野泰志 - 佐藤㯖司 - 武若 聡 (2008）：特性の異なる二つの台風による天竜川河口砂州 の大規模変形, 海工論文集, 第 55 巻, pp.646-650.

真野 明・林 吉近・沢本正樹 (1995)：阿武隈川河口テラス と砂州の干渉作用, 海工論文集, 第42卷, pp.591-595. 